\title{
PENGEMBANGAN FLASHCARD BERBASIS KARAKTER HEWAN UNTUK MENINGKATKAN KEMAMPUAN MENGENAL HURUF ANAK TUNAGRAHITA RINGAN
}

\author{
Rahmat Sanusi ${ }^{1}$, Eka Lenggang Dianasari ${ }^{2}$, Karunia Yulinda Khairiyah ${ }^{3}$, \\ Rudi Chairudin ${ }^{4}$ \\ Fakultas Keguruan dan Ilmu Pendidikan, Universitas Karimun \\ 1rahmatsanusi25@gmail.com, ${ }^{2}$ ekalenggang77@gmail.com, \\ ${ }^{3}$ karuniayulinda@gmail.com, ${ }^{4}$ rudichairudin@gmail.com
}

\begin{abstract}
Letters Identify Process is a basic learning for students to have reading ability, including those with mental disabilities. Based on observations it was found that low reading ability of students with mental disability class 1 due to limited the media to support learning procces. This research aims to produce learning media in the form of flash cards with animal characters to improve the ability to identify the letters in mental disabilities students. The method used is research \& development with quantitative and qualitative descriptive analysis techniques. The results of the data analysis showed that the validator's evaluation and the product trial results obtained a "GOOD" rating. Based on the results of the overall analysis of the data it can be concluded that the flash card product in the animal category is declared appropriate to be used to improve the ability to recognize letters in children with mild mental disability class 1.
\end{abstract}

Keyword: Mental disability, flasch card and learning

Abstrak: Mengenal huruf merupakan pembelajaran dasar bagi peserta didik untuk memiliki kemampuan membaca, termasuk pada anak tuna grahita ringan. Berdasarkan observasi, ditemui rendahnya kemampuan anak tuna grahita ringan kelas 1 di sekolah luar biasa dikarenakan keterbasan media untuk mendukung proses pembelajaran. Penelitian ini bertujuan menghasikan media pembelajaran dalam bentuk flash card dengan karakter hewan untuk meningkatkan kemampuan mengenal huruf pada anak tuna grahita ringan. Penelitian ini merupakan penelitian pengembangan atau research \& development dengan teknik analisa data menggunakan analisa kuantitatif dan kualitatif. Hasil analisa data dari penilaian validator dan uji coba produk mendapatkan hasil dengan kategori "BAIK". Berdasarkan hasil analisa tersebut dapat dinyatakan produk flash card berkarakter hewan layak dan dapat digunakan untuk meningkatkan kemampuan anak dengan tuna grahita ringan kelas 1 SLB dalam mengenal huruf.

Kata Kunci: Tuna grahita, flash card dan pembelajaran 


\section{PENDAHULUAN}

Pendidikan khusus atau pendidikan luar biasa merupakan proses pendidikan yang dirancang khusus bagi peserta didik yang memiliki keterbatasan fisik, mental, bakat dan kecerdasan istimewa. Tujuan utama pendidikan khusus ialah meningkatkan kemandirian dan keterampilan hidup untuk memenuhi kebutuhan pribadi. Khairiyah et al., (2019) menjelaskan setiap anak berhak mendapatkan pendidikan tanpa terkecuali, termasuk anak berkebutuhan khusus. Untuk mendukung hal tersebut, merupakan kewajiban bagi pemerintah dalam menciptakan akses pendidikan guna terselanggaranya pendidikan bagi anak berkebutuhan khusus. Tujuan pendidikan yang hendak dicapai pada anak berkebutuhan khusus secara umum tidak berbeda dengan anak normal lainnya yaitu menjadi manusia seutuhnya, namun secara khusus tujuan pendidikan pada anak berkebutuhan khusus menekankan kemandirian dan survive. Tercapainya proses pendidikan khusus ditandai dengan terbentuknya kemandirian pada anak berkebutuhan khusus atau $\mathrm{ABK}$ sehingga tidak bergantung pada orang lain dalam melakukan aktivitas sehari-hari, memiliki kecakapan hidup dan keberadaannya diakui oleh masyarakat sebagai makhluk sosial yang saling membutuhkan satu sama lain.

Salah satu anak berkebutuhan khusus adalah Tuna Grahita. Tuna grahita adalah individu yang mengalami hambatan intelektual dengan tingkat intelegensinya atau intelligence Quotient (IQ) berada dibawah rata-rata (afektif, kognitif dan psikomotor) yang ditandai dengan ketidakmampuan melakukan adaptasi perilaku baik kepada diri sendiri) dan orang lain. Wulandari (2016) mengungkapkan hambatan intelektual ditandai dengan keterbatasan yang signifikan baik dalamungsi intelektual dan perilaku adaptif seperti yang diungkapkan dalam ranah konseptual, sosial, dan keterampilan adaptif praktis yang terjadi sebelum usia 18 tahun.

Berdasarkan tingkatannya, tuna grahita dibagi menjadi 4 kategori, yaitu: Tunagrahita ringan (IQ : 51-70), tunagrahita sedang (IQ : 3651),tunagrahita berat (IQ : 20-35), tunagrahita sangat berat (IQ dibawah 20). Rojabtiyah, K, Erawati, \& Sunarko (2019) menjelaskan bahwa disabilitas intelektual merupakan istilah resmi yang digunakan di Indonesia untuk menyebut keadaan pada fungsi pikir mengalami gangguan karena tingkat kecerdasan yang dibawah ratarata. Salah satu klasifikasi disabilitas intelektual adalah disabilitas intelektual ringan (mild) dengan IQ antara 50-70.

Proses pembelajaran bagi peserta didik tunagrahita secara umum difokuskan pada kemampuan bina diri dan sosialisasi. Yang, Byrne, \& Chiu (2016) mejelaskan bahwa sebagian besar anak yang mengalami hambatan intelektual tidak mendapatkan pelayanan dan bergantung kepada keluarganya untuk bertahan hidup dan berkembang. Proses pembelajaran untuk peserta didik dengan hambatan Tuna grahita sedang dan berat difokuskan pada mampu latih, artinya anak dengan tuna grahita sedang dan berat dilatih pada peningkatan kemandirian agar tidak bergantung pada orang lain seperti: toilet training, menggunakan pakaian, menggunakan pembalut kewanitaan bagi wanita, menjaga kebersihan diri (menggosok gigi, mandi, mencuci tangan dan lain-lain).. Untuk peserta didik dengan hambatan tuna grahita ringan, proses pembelajaran dapat difokuskan pada mampu didik. Mampu didik atau ajar diartikan proses pembelajaran bagi peserta didik dapat diarahkan pada kemampuan didik seperti membaca, menulis dan berhitung. Proses pembelajaran juga diarahkan pada membentuk kemampuan sosial seperti bekomunikasi dan berinteraksi untuk membangun sikap sosial dimasyarakat. Yucesoy-Ozkan, Gulboy, \& Kaya (2018) memperjelas bahwa anak dengan hambatan intelektual mengalami kesulitan untuk mendapatkan kesempatan dalam membangun interaksi sosial sehingga sangat dibutuhkan aktivitas-aktivitas positif pengisi waktu luang. Nycyk (2018) menambahkan peserta didik dengan hambatan intelektual memiliki batasan fungsi intelektual (belajar, memberikan alasan dan memecahkan masalah) dan adaptasi perilaku khususnya tantangan terhadap kegelisahan dan kepercayan diri dibawah tekanan-tekanan tugas sekolah.

Untuk tercapaianya hasil belajar, maka proses pembelajaran bagi anak tuna grahita ringan harus dirancang seunik dan sesederhana mungkin agar mudah dipahami. Hal ini dimaksudkan memberi kemudahan dengan cara 
sederhana kepada anak dengan tuna grahita ringan karena anak tuna grahita ringanakan mengalami hambatan belajar terutama pada proses mengingat dan menganalisa pelajaran. Sebagai bentuk tanggung jawab pemerintah terhadap akses pendidikan kepada anak berkebutuhan khusus, pemerintah menyedikan sekolah khusus yang diberi nama Sekolah Luar Biasa (SLB). Secara tingkatan, SLB tidak berbeda dari sekolah umum lainya yang diawali dengan Sekolah Dasar, Menengah dan Atas. Perbedaannya terletak pada peserta didik dan proses pembelajaran yang berlangsung.

Pendidikan dasar menjadi proses pendidikan paling penting penentu perjalanan pendidikan berikutnya. Ini dikarenkan pengertian dari pendidikan dasar itu sendiri yang bermakna proses pembelajaran dasar untuk mempersiapkan peserta didik pada pendidikan menengah dan atas. Seperti sekolah dasar lainnya, anak berkebutuhan khusus diharapkan memiliki keterampilan dasar hidup yaitu membaca, menulis dan berhitung. Wijanarko (2019) menyebutkan salah satu dasar keterampilan berbahasa adalah keterampilan membaca. Utama (2017) menambahkan bahwa tujuan pendidikan yang diturun pada Peraturan Menteri Pendidikan Dan Kebudayaan Republik Indonesia Nomor 146 Tahun 2014 Tentang Kurikulum 2013 Pendidikan Anak Usia Dini dengan umur sejak lahir sampai usia 6 tahun adalah kesiapan mengenal aksara dengan baik dan benar. Diperkuat dengan undang-undang sistem pendidikan Nasional tahun 2003 pendidikan diselenggarakan untuk mengembangkan budaya membaca, menulis dan berhitung bagi seluruh masyarakat Indonesia. Deporter \& Mike dalam Rosyida (2018) memperkuat bahwa membaca merupakan proses yang kompleks yang dapat dicapai oleh manusia. Hampir semua orang dapat membaca pada usia 6-7 tahun.

Membaca adalah kemampuan menyimpulkan gabungan beberapa kata yang membentuk kalimat sehingga mendapatkan informasi. Teknik dasar membaca sendiri dimalai dari kemampuan mengenal huruf. atau abjad. Proses ini menjadi dasar pada siswa sekolah dasar tingkat bawah pada kelas satu tidak terkecuali pada sekolah luar biasa. Berdasarkan observasi dilakukan di SLB Negeri Karimun ditemukan permasalahan siswa tunagrahita ringan kelas 1, yaitu masih kurang kemampuan dalam mengenal huruf, sehingga perlu perhatian dan pembelajaran yang tepat pada siswa tersebut. Ini dapat dilihat pada saat guru mengenalkan dan menerangkan huruf kepada siswa dengan menulis secara langsung di papan tulis, tetapi siswa belum dapat memahami tentang konsep dari huruf yang dijelaskan. Hasilnya siswa cendrung ragu dalam menyebutkan huruf, terutama pada pelafalan huruf semisal (a) dibaca (u) kadang (i) dibaca (e). Saat guru memberikan intruksi untuk menunjukkan mana huruf (p) yang ditulis dipapan tulis, siswa akan menunjukkan huruf (q) dan ketika di minta untuk kembali menunjukan huruf (a) siswa tersebut memilih untuk diam yang menandakan siswa lupa. Hasil observasi ini memberikan gambaran masih rendahnya kemampuan dalam mengenal huruf bagi anak dengen tuna grahita ringan. Salah satunya disebabkan terbatasnya sumber media pembelajaran sehingga menurunkan antusias siswa dalam mengikuti proses pembelajaran.

Rachmawati \& Ummah (2004) menjelaskan untuk meningkatkan proses pembelajaran peserta didik perlu adanya strategi khusus untuk mendukung pencapaian peserta didik. Sehubungan dengan kondisi tersebut, perlu dilakukannya usaha perbaikan dalam proses pembelajaran, salah satunya adalah dengan menggunakan dan mengoptimalkan media serta metode pembelajaran yang dapat menurunkan kejenuhan, menarik dan menyenangkan bagi siswa. didik yang kondusif, ramah dan menyenangkan bagi peserta didik. Ida \& Agung (2016) mengungkapkan bahwa penggunaan media dapat meningkatkan kemampuan kemandirian pada anak berkebutuhan khusus. Proses pembelajaran memerlukan rancangan inovasi dan kreatif baik metode ajar, perangkat hingga media pembelajaran agar proses pembelajaran menjadi tidak monoton. Amumpuni \& Rahmasari (2019) menambahkan bahwa pembelajaran melalui media memberikan nilai praktis, menguasai perbedaan kemampuan setiap anak, mengganti objek yang besar menjadi kecil dan dapat membawanya ke dalam kelas.

Salah media yang selalu digunakan untuk mendukung pembelajaran khususnya pada anak berkebutuhan khusus adalah flash card. Berdasarkan gambaran obeservasi, flash card 
yang digunakan cendrung flasch card dalam bentuk benda disekeling, kendaraan, buah hewan yang semuanya digabung menjadi satu tidak dikekompokkan berdasarkan kesamaan karakteristik benda sehingga siswa cendrung tidak tertarik dan jenuh.

Flashcard adalah media visual dengan ukuran tertentu dalam bentuk kartu. Ukurannya yang disesuaikan dengan kebutuhan, namun relatif tidak terlalu besar. Flash card sering jug disebut kartu gambar, karena setiap kartunya berisikan gambar baik dalam bentuk foto atau ilustrasi animasi. Flash card sering digunakan sebagai media pengenal benda-benda bagi anakanak. Dalam pengembangannya flash card telah banyak perubahan dengan mengkombinasikan huruf atau angka yang dihubungkan dengan abjad pada benda yang menjadi objek utama pada flash card. Media flashcard dapat digunakan untuk melatih anak mengenal huruf, mengeja dan memperkaya kosa kata serta sebagai petunjuk dan rangsangan bagi anak.

Melihat dari fungsi dan bentuknya, Flashcard dapat dikembangkan menjadi media pembelajaran pada siswa tunagrahita ringan karena siswa dapat memanfaatkan indera penglihatannya dalam memahami pesan materi yang ada pada media flash card tersebut. Selain itu, flash card dapat berubah fungsi sebagai media bermain seperti kartu remi. Penggunanaan flash card sebagai media bermain dihubungkan dengan kebiasaan anak-anak yang senang bermain termasuk anak dengan hambatan intelektua ringan. Yucesoy-Ozkan et al (2018) menjelaskan bahwa hasil penelitian menyebutkan anak dengan hambatan intelektual dapat bermain berbagai macam mainan di waktu luang, termasuk bermain kartu seperti UNO, Soiltaire dan lain sebagainya. memperkuat pernyataan di atas, hasil penelitian Maulana \& Hastuti (2017) menyimpulkan penggunaan kartu tanda baca efektif dalam meningkatkan kemampuan menulis sederhana anak tuna grahita ringan, hal ini disebabkan penggunaan media kartu dapat meningkatkan fokus anak melalui kagiatan bermain dengan menggunakan kartu.

Berangkat dari paparan tersebut, untuk mengoptimalkan fungsi flash card, penulis tertarik untuk mengembangkan flash card berbasis karakter hewan dalam meningkatkan kemampuan mengenal huruf. Karakter hewan dipilih untuk memudahkan siswa dengan tunagrahita ringan dalam mengimajinasikan dan menghubungkan karakter hewan dengan bentuk huruf, seperti huruf (c ) digambarkan dengan hewan cacing yang melingkar berbentuk (c ). Huruf (j) digambarkan dengan jerapah leher jerapah. Pemilihan karakter hewan karena hewan merupakan karatekter yang paling mudah diingat dan bentuknya lebih sering ditemui dalam berbagai macam karakter seperti boneka, kartun, stiker hingga dalam kehidupan sehari-hari.

Pengembangan flash card berbasis karakter hewan diharapkan memberikan dampak positif dalam menjawab kebutuhan pendidikan khusus untuk menghasilkan media pembelajaran yang layak untuk meningkatkan kemampuan mengenal huruf pada anak tuna grahita ringan. Media ini menjadi salah satu media efektif yang dapat membantu guru untuk mengoptimalkan proses pembelajaran khususnya bagi anak tuna grahita ringan dalam mengenal huruf.

\section{METODOLOGI PENELITIAN}

Metode yang digunakan dalam penelitian ini adalah research \& development (penelitian pengembangan) dengan konsep yang dikembangkan oleh pendidikan Borg and Gall yang terdiri dari beberapa langkah pengembangan yaitu:

\section{Penelitian Pendahuluan untuk megumpulkan Potensi Masalah, Informasi dan Observasi Lapangan}

Peneliti mengumpulkan informasi dengan melakukan obesrvasi melihat langsung proses pembelajaran subjek peneltian. Selanjutnya wawancara terhadap guru kelas I SD tunagrahita ringan SLBN Karimun tentang pembelajaran Bahasa Indonesia dan mediamedia yang dibutuhkan. Pada langkah ini dilakukan dengan tujuan untuk mengetahui bagaimana proses pembelajaran Bahasa Indonesia khususnya mengenal huruf dan media apa yang digunakan oleh siswa tunagrahita ringan untuk membantu selama proses pembelajaran mengenal huruf.

\section{Analisa Informasi dan Perencanaan Pengembangan Model}

Setelah melakukan pengumpulan informasi awal, langkah berikutnya peneliti 
menganalisa media apa yang tepat dikembangkan untuk membantu proses pembelajaran mengebal huruf bagi anak tuna grahita ringan. Perencanaan produk didasari pada paa yang disukai oleh anak tuna grahita ringan, merancang media menjadi unik dan kreatif dan meningkatkan fokus subjek pada media. Perecanaan produk sampai pada tahapan mengembangan media flash card berbasis karater hewan. Hewan dipilih karena semua anak-anak menyukai dan mengenal hewan, selain itu karakter hewan telah diimplementasikan kedalam berbagai bentuk seperti boneka, mainan, kartun dan lain sebagainya.

\section{Validasi dan Revisi Desain}

Sebelum dilakukan uji coba, produk perlu divalidasi oleh ahli materi Sanusi \& Widiyanto (2018) menjelaskan bahwa Validasi ahli bertujuan untuk mendapatkan pengesahan dan reliabilitas pada model yang dikembangkan. Pengembangan media flash card berbasis hewan melibatkan dua validator yang kompeten pada bidangnya. Ahli Materi dan Media divalidasi oleh Karunia Yulinda Khairiyah, S.Pd.M.Pd. yang merupakan pakar pendidikan luar biasa dan Irwan Indra, S.T yang merupakan pakar desain grafis dan multimedia.

\section{Uji Coba Produk dan Revisi}

Uji coba produk dilakukan di Sekolah SLB Negeri Karimun pada siswa kelas 1 sebanyak tiga orang siswa dengan tuna grahita ringan dan didampingi oleh guru wali kelas. Uji coba dilakukan sebanyak enam kali selama dua minggu. Selama ujicoba sebanyak $6 x$ penulis mencatat setiap kejadian dan prosesnya yang terdiri dari ketercapaian penggunaan produk terhadap peningkatan kemampuan mengenal huruf, kekurangan dan kelebihan produk. Hasil tersebut menjadi evaluasi sehingga produk direvisi agar menjadi lebih baik.

\section{Pembuatan Produk Final}

Setelah tahapan validasi, ujicoba dan revisi selesai maka dilakukan tahapan penyelesaian produk. Produk dicetak dengan bentuk kartu dengan ukuran $12 \mathrm{~cm}$ x $8 \mathrm{~cm}$. Setiap huruf dicetak pada satu kartu sehingga terdapat 26 kartu huruf atau flash card berbasis karakter hewan.

\section{HASIL DAN PEMBAHASAN}

Untuk menilai kelayakan produk maka dilakukan uji coba produk. Uji coba dilakukan kepada tiga orang siswa dengan tuna grahita ringan dan guru kelas sebagai pengguna media. Uji coba bertujuan untuk mengetahui kemampuan mengenal huruf dengan dua indikator yaitu kemampuan menyebutkan huruf dan kemampuan menuliskan huruf. Sebelum dilakukan uji coba, peneliti melakukan pre-terlebih dahulu kepada subjek penelitian sebelum menggunakan produk dengan perolehan data sebagai berikut:

Tabel 1. Hasil Pre-test Kelayakan Produk

\begin{tabular}{lcccccc}
\hline \multirow{2}{*}{ Kategori } & \multicolumn{5}{c}{ Indikator } \\
\cline { 2 - 7 } & \multicolumn{3}{c}{ Menyebutkan Huruf } & \multicolumn{3}{c}{ Menulis Huruf } \\
\cline { 2 - 7 } & $\mathrm{f}$ & Skor & $\%$ & $\mathrm{f}$ & Skor & $\%$ \\
\hline Baik Sekali & 0 & - & - & - & - & - \\
Baik & 0 & - & - & - & - & - \\
Cukup & 1 & 1.61 & 33.3 & - & - & - \\
Kurang & 2 & 1.43 & 36.7 & 3 & 1.45 & 100 \\
Kurang Sekali & 0 & - & - & - & - & - \\
\hline Total & $\mathbf{3}$ & $\mathbf{3 . 0 4}$ & $\mathbf{1 0 0}$ & $\mathbf{3}$ & $\mathbf{1 . 4 5}$ & $\mathbf{1 0 0}$ \\
\hline Rata-Rata & & $\mathbf{1 . 5 2}$ (Kurang) & & $\mathbf{1 . 4 5}$ (Kurang) \\
\hline
\end{tabular}


Berdasarkan data di atas menunjukan masih rendahnya kemampuan siswa dalam mengebal huruf. Untuk indikator menyebutkan huruf hanya 1 orang masuk kategori CUKUP dan 2 siswa lainnya masuk kategori RENDAH. Pada indikator menulis huruf, keseleuruhan subjek penelitian mendapatkan skor yang tidak memuaskan dengan kategori RENDAH. Dari hasil pre-tes didapat informasi masih rendahnya kemampuan mengenal huruf pada siswa tuna grahita ringan.

Setelah memperoleh data pre-test, selanjutnnya adalah menguji cobakan produk yang telah di validasi ahli. Setelah melakukan ujicoba produk sebanyak $8 x$ pertemuan dalam minggu diproleh data sebagai berikut:

Tabel 2. Hasil Post-test Kelayakan Produk

\begin{tabular}{lcccccc}
\hline \multirow{2}{*}{ Kategori } & \multicolumn{5}{c}{ Indikator } \\
\cline { 2 - 7 } & \multicolumn{3}{c}{ Menyebut Huruf } & \multicolumn{3}{c}{ Menulis Huruf } \\
\cline { 2 - 7 } Baik Sekali & 0 & - & - & 0 & - & - \\
Baik & 1 & 2.45 & 33.3 & 0 & - & - \\
Cukup & 2 & 1.62 & 36.7 & 3 & 1.66 & 100 \\
Kurang & 0 & - & - & - & - & - \\
Kurang Sekali & 0 & - & - & - & - & - \\
\hline \multicolumn{1}{c}{ Total } & $\mathbf{3}$ & $\mathbf{4 . 0 7}$ & $\mathbf{1 0 0}$ & \multicolumn{4}{c}{$\mathbf{1 . 6 6}$} & $\mathbf{1 0 0}$ \\
\hline Rata-Rata & \multicolumn{3}{c}{$\mathbf{2 . 0 3 5}$ (Cukup) } \\
\hline \multicolumn{7}{c}{}
\end{tabular}

Berdasarkan Hasil uji coba produk (posttest) didapat informasi terjadi peningkatan kemampuan siswa tuna grahita ringan dalam mengenal huruf. Untuk indikator menyebutkan huruf, 1 siswa masuk dalam kagetori BAIK dan dua siswa masuk dalam kategori CUKUP dengan rata-rata skor sebesar 2.035 dengan kategori CUKUP. Untuk indikator menulis huruf keseluruhan siswa memperoleh skor sebesar 1.66 dengan kategori CUKUP.

Tabel 3. Hasil Penilaian Validator

\begin{tabular}{cccc}
\hline No & Validator & Skor & Keterangan \\
\hline 1 & Validator Meteri & 3.0 & Baik \\
2. & Validator Media & 3.1 & Baik \\
3. & Validator Pengguna & 2.9 & Baik \\
\hline & Rata-Rata & $\mathbf{3 . 0}$ & BAIK \\
\hline
\end{tabular}

Data di atas menunjukkan validator materi memberikan rata-rata skor sebesar 3.0 dengan kategori baik. Validator media memberikan skor sebesar 3.1 dengan kategori baik dan
Langkah penilain selanjutnya adaah menganalisa penilaian dari para ahli untuk menentukkan kelayakan produk yang dikembangkan agar memiliki isi atau materi yang valid, penggunaan yang tepat sasaran dan produk yang dikembangkan dibutuhkan. Berdasarkan penilaian para ahli dapat disimpulkan sebagai berikut: 
diperoleh nilai rata-rata sebesar 3.0 dengan kategori BAIK.

Berdasarkan paparan data di atas, daat dilihat terdapat perbedaan yang signifikan pada kemampuan anak tuna grahita ringan mengenal huruf sebelum dan sesudah menggunakan flash card berkarakter hewan.
Dari data menunjukan secara rata-rata hasil pre-test menujukkan skor sebesar 1.48 dengan kategori RENDAH. Pada hasil post test perolehan skor sebesar 1.84 kategori CUKUP dengan selisih sebesar 0.36. untuk lebih jelas dapat dilihat pada grafik di bawah ini:

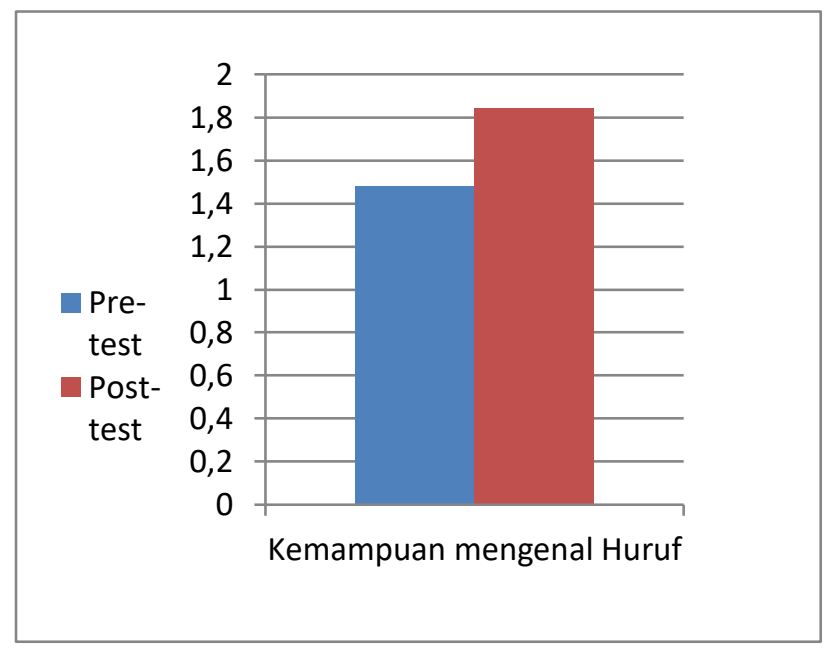

Pada grafik menunjukkan terdapat selisih perbedaan sebelum dan sesudah. Meskipun kecil peningkatan ini memberikan kesimpulan bahwa produk memberikan perubahan positif.

Pengembangan produk didasari pada permasalahan yang terjadi di lapangan pada saat proses belajar mengajar di sekolah luar biasa khususnya pada pelajaran mengenal huruf. Keterbatasan media menjadi salah satu penyebab gaya dan metode mengajar guru yang monoton sehingga anak tidak tertarik dalam menangkap pelajaran. Khususnya pada anak berkebutuhan khusus yang menuntut proses pembelajaran yang unik, menarik dan khusus sesuai dengan yang dibutuhkan oleh anak untuk tercapainya tujuan pembelajaran.
Flash card huruf berkarakter hewan secara umum terlihat sederhana. Kombinasi hewan dan huruf menjadi dasar pengembangan. Pengembangan produk ini merupakan upaya untuk mempermudah siswa dan menawarkan akses dalam singkat (short cut) dalam belajar mengenal huruf. Misalnya,huruf (a) dirancang dengan mengkombinasikan burung. Tujuannya adalah ketika siswa melihat bentuk burung, otak akan memberikan informasi, misalnya siswa akan dengan cepat mengimajinasikan bahwa burung adalah huruf (a) dan huruf (b), cacing huruf (c), gajah adalah huruf (g) dan karakter hewan lainya yang sesuai dengan huruf.
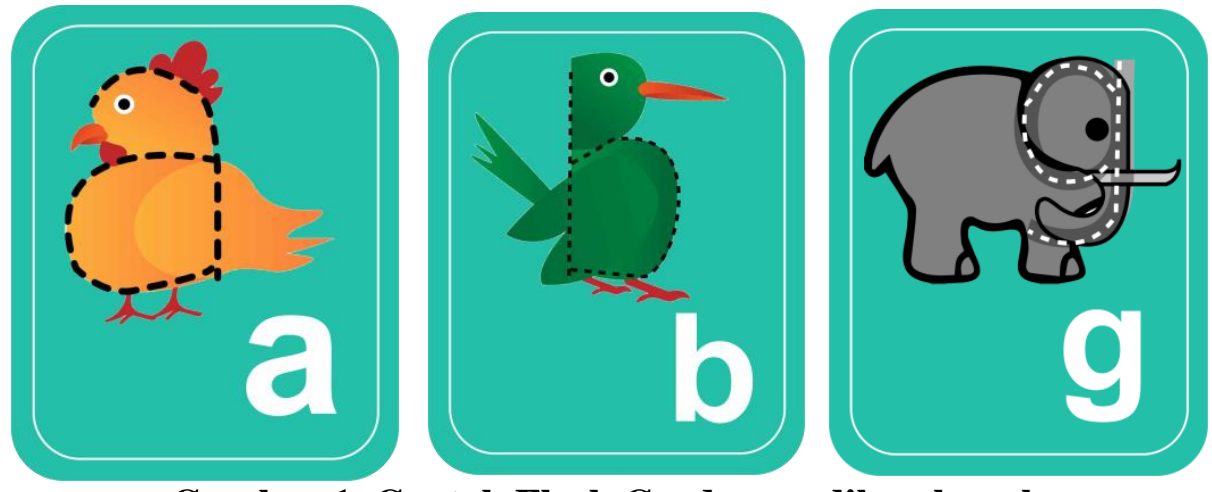

Gambar 1. Contoh Flash Card yang dikembangkan 
Pengembangan produk secara umum masih diperlukan penyempurnaan yang lebih baik, namum secara khusus kemanfaatan dan kebutuhan di lapangan hasil analisa data menunjukan produk yang dikembangkan dikategorikan BAIK. Dalam penggunaannya, produk flash card ini memberikan variasi media pembelajaran bagi anak berkebutuhan khusus, khususnya anak tuna grahita ringan dalam proses belajar mengenal huruf.

\section{SIMPULAN}

Berdasarkan hasil pengembangan yang telah dilakukan dan analisa data yang dipaparkan sebelumnya, menunjukan secara umum produk yang dikembangkan yaitu flash card berkarakter hewan untuk mengenal huruf bagi anak tuna grahita ringan mendatkan penilaian dengan kategori BAIK dari validator Ahli. Penilaian validator ahli materi menujukkan kemanfaatan produk, inovasi dan gagasan yang merupakan upaya untuk meningkatkan kemampuan imajinasi pada anak tuna grahita ringan. Imajinasi ini nantinya akan berkembang menjadi kemampuan menganalisa dan daya ingat. Konsep ini sangat dibutuhkan mengingat anak tuna grahita ringan mengalami kesulitan dalam menganalisa dan mengingat pembelajaran. membuat konsep dalam mengenal huruf.

Dari sisi media, masih banyak ilustrasi yang perlu dikembangkan agar produk menjadi lebih baik namum secara tujuan dan konsep, menggunakan bentuk fisik hewan untuk dihubungkan pada jenis huruf bukan hal yang mudah mengingat harus ada kesamaan pola huruf dan bentuk hewan dalam membuat ilustrasi yang tampak nyata sesuai dengan kebutuhan. Dari sisi validator media, produk dinilai BAIK. Dari validator pengguna memberikan gambaran bahwa kondisi proses pembelajaran bagi anak berkebutuhan khusus sangat kurang dalam inovasi media sehingga keberadaan produk flash card ini menjadi salah satu upaya positif dalam menghasilkan produk yang variatif dan inovatif guna mendukung proses pembelajaran di sekolah SLB.

Pada uji coba lapangan menunjukkan peningkatan hasil yang signifikan pada siswa tuna grahita ringan dalam mengenal huruf setelah menggunakan produk yang dikembangkan. Hal ini diperkuat oleh hasil penelitian Warman (2017) tentang pengembangan media puzzle untuk meningkatkan minat belajar matematika. Warman menjelaskan salah satu kesulitan dari anak tuna grahita ringan adalah memiliki keterbatasan dalam hal berfikir abstrak untuk membayangkan konsep pembelajaran secara kompleks. Pengembangan flash card bertujuan untuk membantu anak tuna grahita. Berdasarkan hasil penilaian validator dan uji coba produk dapat diambil kesimpulan bahwa produk yang dikembangkan layak digunakan untuk meningkatkan kemampuan dalam mengenal huruf pada anak tuna grahita ringan kelas 1 SLB.

\section{DAFTAR PUSTAKA}

Ghofur, A. (2019). The Use Of Media For Science Teaching In Islamic Schools. JPE (Jurnal Pendidikan Edutama), 6(1), 59-64. https://ejurnal.ikippgribojonegoro.ac.i d/index.php/JPE/article/view/106/0.

Ida, N. N., \& Agung, K. (2016). The Effects Of The Use Of Series Card Media On Toilet Training Skill Toward Autism Children (Pengaruh Penggunaan Media Kartu Gambar Berseri Terhadap Keterampilan. P3Lb, 3(2), 103-108. http://journal2.um.ac.id/index.php/jpp $\mathrm{plb} /$ article/view/4350

Khairiyah, K. Y., Lestari, T., Dianasari, E. L., Wisma, N., Karimun, U., \& Abstract, A. (2019). Pelatihan Kompetensi Guru Sekolah Inklusif Dalam Pemahaman Anak Berkebutuhan Khusus Di Kabupaten Karimun. Jurnal Pendidikan MINDA, l(1), 61-69. http://www.ejurnal.universitaskarimun ac.id/index.php/mindafkip/article/vie $\underline{w} / 20$. 
Maulana, L. A., \& Hastuti, W. D. (2017). Media Kartu Tanda Baca dalam Meningkatkan Kemampuan Menulis Sederhana Siswa Tunagrahita. Jurnal Ortopedagogia, 3(1), 3-5. http://journal2.um.ac.id/index.php/jo/a rticle/view/4969

Nycyk, M. (2018). Education Support for Adults With an Intellectual Disability: A Tutor's Reflection. Adult Learning, 29(4),

176-178. https://doi.org/10.1177/104515951878 3981

Rachmawati, A., \& Ummah, U. S. (2016). The Effect Of Train Number Game Toward The Summation Arithmatic Ability For Student With Intellectual Disability. Jurnal Penelitian Dan Pengembangan Pendidikan Luar Biasa, 3(1), 10-15. http://journal2.um.ac.id/index.php/jpp plb/article/view/4335.

Rojabtiyah, U. R., K, P. G., Erawati, E., \& Sunarko. (2019). Efektivitas promosi kesehatan menggunakan metode index card match dan cuci tangan pada disabilitas intelektual ringan. Jurnal Pendidikan Khusus, 15(36), 68-73. http://dx.doi.org/10.21831/jpk.v15i2.2 6301

Rosyida, F. (2018). Pengaruh Kemampuan Membaca Dan Aktivitas Belajar Terhadap Hasil Belajar Bahasa Indonesia. Jurnal Pendidikan Edutama, 5(1), 23. https://doi.org/10.30734/jpe.v5i1.107

Sanusi, R., \& Widiyanto, W. (2018). Pengembangan model aquarobic exercise untuk pembakaran lemak pada overweight. Jurnal Keolahragaan, 6(2), 139-149. https://doi.org/10.21831/jk.v0i0.8560

Utama, F. (2017). Pengenalan Aksara Melalui Media. Iqra': Jurnal Kajian
Ilmu Pendidikan, 2(2), 433-457. https://doi.org/10.25217/ji.v2i2.169. https://journal.iaimnumetrolampung.a c.id/index.php/ji/article/view/169

Warman, E. (2017). Mengembangkan Minat Belajar Anak Tunagrahita Ringan Menggunakan Media Pembelajaran Puzzle Angka Di Skh Negeri 02 Kabupaten Lebak. Jurnal Unik Pendidikan Luar Biasa Untirta, 2(1). Retrieved from http://jurnal.untirta.ac.id/index.php/U NIK/article/view/3545

Wijanarko, A. G. (2019). Strategi Tua Tuo Untuk Meningkatkan Ketrampilan Berbicara (Tembang Macapat). Jurnal Iqra': Kajian Ilmu Pendidikan, 4(1), 28-41.

https://doi.org/10.25217/ji.v4i1.479. https://journal.iaimnumetrolampung.a c.id/index.php/ji/article/view/479.

Wulandari, D. R. (2016). Strategi Pengembangan Perilaku Adaptif Anak Tunagrahita Melalui Model Pembelajaran Langsung. Jurnal Pendidikan Khsusus, 12(1), 1-11. https://journal.uny.ac.id/index.php/jpk /article/view/12840/9005

Yang, X., Byrne, V., \& Chiu, M. Y. L. (2016). Caregiving Experience for Children with Intellectual Disabilities among Parents in a Developing Area in China. Journal of Applied Research in Intellectual Disabilities, 29(1), 4657. https://doi.org/10.1111/jar.12157

Yucesoy-Ozkan, S., Gulboy, E., \& Kaya, F. (2018). Teaching children with intellectual disabilities through video prompting: Smartphone vs. tablet. International Journal of Early Childhood Special Education, 10(1), 32-48.

https://doi.org/10.20489/intjecse.4544 33 
46 JURNAL PENDIDIKAN EDUTAMA, Vol 7, No. 2, Juli 2020 